\title{
Annual cycle of planktonic primary productivity off the Romanian Black Sea coast
}

\author{
Alexandru S. Bologa ${ }^{1}$, Hilarius V. Skolka ${ }^{1}$ and Petre T. Frangopol ${ }^{2}$ \\ 1 Romanian Marine Research Institute, R-8700 Constantza, Romania \\ ${ }^{2}$ Institute of Physics and Nuclear Engineering, R-76900 Bucharest-Măgurele, P.O. Box 5206, Romania
}

\begin{abstract}
Data are presented on planktonic primary productivity $(0,5$ and $10 \mathrm{~m}$ depth) collected in 1982 from a station 1.2 nautical miles off Constantza on the Romanian Black Sea coast. Primary productivity was measured using the ${ }^{14} \mathrm{C}$ technique under in situ conditions. Counting was done in a liquid scintillation spectrometer. Simultaneously, determinations of chlorophyll and microscopic enumeration of phytoplankton (density and biomass) were made. Mean values of primary productivity at 0,5 and $10 \mathrm{~m}$ were $5.2,1.4$ and $1.0 \mathrm{mg} \mathrm{C} \mathrm{m}^{-3} \mathrm{~h}^{-1}$ respectively; the water column value was $2.3 \mathrm{mg}$ $\mathrm{C} \mathrm{m}^{-2} \mathrm{~h}^{-1}$.
\end{abstract}

\section{INTRODUCTION}

Some biological problems of the north-western shelf of the Black Sea have been discussed by Zaitsev (1979). Two problems considered are the influence of $r i v e r s$ and of industrial, agricultural and urban wastes on environmental biology. Both factors tend to increase phytoplankton biomass and primary productivity.

The study of planktonic primary productivity in Romanian coastal waters has been continued in the Constantza sector (Bologa et al., 1980, 1981; Bologa and Frangopol, 1982) during 1982. For the first time in this sector in situ determinations were performed both at depths of $0 \mathrm{~m}$ and at 5 and $10 \mathrm{~m}$. The data obtained in the present study complement our knowledge on the bioproductive level of these marine coastal waters.

\section{MATERIAL AND METHODS}

Phytoplankton samples were collected every month from a station (data available since 1955) situated 1.2 nautical miles off the Constantza sector of the Romanian Black Sea Coast $\left(44^{\circ} 10^{\prime} \mathrm{N}\right.$ lat., $28^{\circ} 41^{\prime} \mathrm{E}$ long.). Samplings were obtained from 0,5 and $10 \mathrm{~m}$ depths.

Light measurements were made by means of an Ogawa Seiki underwater illuminometer (Type OSK $3174)_{i}$ values $(\mathrm{lx})$ were transformed in energetic units $\left(\mathrm{W} \mathrm{m}^{-2}\right.$ ) by means of a nomogram (cf. Kubin, 1971, from Gaastra, 1959) (Table 1). Total inorganic carbon content of the sea water was determined by total carbonic alkalinity analysis (cf. Protecția calității apelor, 1967).

The ${ }^{14} \mathrm{C}$ method (Steemann Nielsen, 1952) was used for determination of primary productivity. Three light and 1 dark bottle(s) containing phytoplankton were inoculated each with $25 \mu \mathrm{Ci}(925 \mathrm{kBq})$ aqueous $\mathrm{NaH}^{14} \mathrm{CO}_{3}$ solution and incubated in situ at the depths mentioned. All samples were exposed for $4 \mathrm{~h}$ (10,00 to $14.00 \mathrm{~h}$ ) and fixed with formaline at the end of incubation.

Samples were filtered under vacuum, on Millipore membrane filters HA 04700 (pore size $=0.45 \mu \mathrm{m}$ ). Filters were washed with a $2 \% \mathrm{HCl}$ solution and sea water.

The filters, preserved in Packard-type vials (with previously determined background) were counted with an automatic Nuclear Enterprises spectrometer (Type $8310 / 1 / 2$ ) at $5^{\circ} \mathrm{C}$, by liquid scintillation counting. The following mixture was used for measuring the ${ }^{14} \mathrm{C}$ activity: $3 \mathrm{ml}$ dioxan (for filter solubilization) and $5 \mathrm{ml}$ Unisolve Liquid Scintillator. Samples were measured with an efficiency of $83 \%$. Background and quenching corrections were applied to the results. Each sample was counted 3 times (1 min duration).

Computation of planktonic primary productivity was carried out by means of the formula of Vinberg et al. (1960). Results are expressed in $\mathrm{mg} \mathrm{C} \mathrm{m}{ }^{-3}$ (or $\left.\mathrm{m}^{-2}\right) \mathrm{h}^{-1}$. Values for dark (control) bottles were neither subtracted from photosynthetic assimilation values, 
nor calculated as percentage of the latter, but were considered as such (Sournia, 1973).

Chlorophyll from the 3 depths was spectrophotometrically measured with Beckman M 25 equipment (Richards and Thompson, 1952; Strickland and Parsons, 1965); chlorophyll a concentrations were calculated using the trichromatic equations (Unesco, 1966).

Qualitative and quantitative phytoplankton determinations were made by employing the sedimentation method (Morozova-Vodyanitskaya, 1948, 1954) for establishing taxonomic composition and weight of the major groups of primary producers; both density (total cell number) and biomass (standard cell measurements multiplied by cell numbers; cf. Morozova-Vodyanitskaya, 1954, completed by Skolka, pers. comm.) analyses were carried out; these determinations exclude nanoplankton species.
Values of primary productivity, chlorophyll a, phytoplankton density and biomass were calculated for the water column according to the scheme generally adopted for the Black Sea (Morozova-Vodyanitskaya, 1954).

\section{RESULTS AND DISCUSSION}

Environmental factors such as light (irradiance), temperature, $\mathrm{pH}$, salinity and total inorganic carbon were measured along with primary productivity (Table 1).

The results on primary productivity of the Constantza sector, nearshore, in 1982 (Table 2) list the highest value, $24.7 \mathrm{mg} \mathrm{C} \mathrm{m} \mathrm{m}^{-3} \mathrm{~h}^{-1}$, at $0 \mathrm{~m}$ in Jul. In both of the other 2 layers, lower values, ranging between 0.2 and $2.7 \mathrm{mg} C \mathrm{~m}^{-3} \mathrm{~h}^{-1}(5 \mathrm{~m})$ and between 0.1 and 3.0

Table 1. Hydrological data of the sea water in the Constantza sector, 1982

\begin{tabular}{|c|c|c|c|c|c|c|}
\hline Month & Depth (m) & $\begin{array}{c}\text { Irradiance } \\
(10.00 \mathrm{~h})\left(\mathrm{W} \mathrm{m}^{-2}\right)\end{array}$ & $\begin{array}{c}\text { Temperature } \\
\left({ }^{\circ} \mathrm{C}\right)\end{array}$ & $\mathrm{pH}$ & $\mathrm{S} \%$ & $\begin{array}{l}\text { Total inorganic } \\
\text { carbon }\left(\mathrm{mg} \mathrm{l}^{-1}\right)\end{array}$ \\
\hline $\operatorname{Jan} 26$ & $\begin{array}{r}0 \\
5 \\
10\end{array}$ & $\begin{array}{r}>11.7 \\
0.9 \\
0.2\end{array}$ & $\begin{array}{l}1.0 \\
1.0 \\
1.0\end{array}$ & $\begin{array}{l}8.2 \\
8.1 \\
8.1\end{array}$ & $\begin{array}{l}14.33 \\
14.85 \\
14.85\end{array}$ & $\begin{array}{l}39.09 \\
38.91 \\
38.33\end{array}$ \\
\hline Feb 16 & $\begin{array}{r}0 \\
5 \\
10\end{array}$ & $\begin{array}{c}>15.6 \\
0.5 \\
0.02\end{array}$ & $\begin{array}{l}1.5 \\
2.0 \\
2.0\end{array}$ & $\begin{array}{l}8.1 \\
8.3 \\
8.3\end{array}$ & $\begin{array}{l}13.95 \\
14.33 \\
14.07\end{array}$ & $\begin{array}{l}40.45 \\
40.45 \\
39.24\end{array}$ \\
\hline Mar 26 & $\begin{array}{r}0 \\
5 \\
10\end{array}$ & $\begin{array}{c}>24.1 \\
0.4 \\
0.01\end{array}$ & $\begin{array}{l}3.0 \\
3.0 \\
3.0\end{array}$ & $\begin{array}{l}8.3 \\
8.3 \\
8.1\end{array}$ & $\begin{array}{l}13.82 \\
14.67 \\
15.37\end{array}$ & $\begin{array}{l}41.04 \\
39.83 \\
38.02\end{array}$ \\
\hline Apr 26 & $\begin{array}{r}0 \\
5 \\
10\end{array}$ & $\begin{array}{r}>29.7 \\
3.0 \\
0.7\end{array}$ & $\begin{array}{l}9.5 \\
9.5 \\
9.0\end{array}$ & $\begin{array}{l}8.2 \\
8.4 \\
8.4\end{array}$ & $\begin{array}{l}11.17 \\
11.42 \\
12.45\end{array}$ & $\begin{array}{l}38.02 \\
38.02 \\
38.02\end{array}$ \\
\hline May 06 & $\begin{array}{r}0 \\
5 \\
10\end{array}$ & $\begin{array}{r}>30.6 \\
27.6 \\
7.4\end{array}$ & $\begin{array}{l}7.5 \\
7.0 \\
7.0\end{array}$ & $\begin{array}{l}8.1 \\
8.1 \\
8.1\end{array}$ & $\begin{array}{l}18.22 \\
18.12 \\
18.31\end{array}$ & $\begin{array}{l}41.05 \\
40.44 \\
40.44\end{array}$ \\
\hline Jun 16 & $\begin{array}{r}0 \\
5 \\
10\end{array}$ & $\begin{array}{r}>32.8 \\
>32.8 \\
22.9\end{array}$ & $\begin{array}{r}13.5 \\
11.5 \\
9.5\end{array}$ & $\begin{array}{l}8.2 \\
8.2 \\
8.3\end{array}$ & $\begin{array}{l}12.32 \\
12.42 \\
12.76\end{array}$ & $\begin{array}{l}41.49 \\
41.49 \\
41.49\end{array}$ \\
\hline Jul 26 & $\begin{array}{r}0 \\
5 \\
10\end{array}$ & $\begin{array}{r}>31.1 \\
1.4 \\
0.2\end{array}$ & $\begin{array}{l}24.0 \\
23.0 \\
21.0\end{array}$ & $\begin{array}{l}8.8 \\
8.6 \\
8.4\end{array}$ & $\begin{array}{l}13.77 \\
15.17 \\
16.20\end{array}$ & $\begin{array}{l}30.12 \\
36.20 \\
38.02\end{array}$ \\
\hline Aug 13 & $\begin{array}{r}0 \\
5 \\
10\end{array}$ & $\begin{array}{r}>28.3 \\
5.7 \\
0.6\end{array}$ & $\begin{array}{l}25.0 \\
24.0 \\
24.0\end{array}$ & $\begin{array}{l}8.4 \\
8.5 \\
8.7\end{array}$ & $\begin{array}{l}14.15 \\
14.24 \\
14.33\end{array}$ & $\begin{array}{l}33.78 \\
33.78 \\
34.38\end{array}$ \\
\hline Sep 24 & $\begin{array}{r}0 \\
5 \\
10\end{array}$ & $\begin{array}{r}>24.1 \\
2.4 \\
0.5\end{array}$ & $\begin{array}{l}22.0 \\
22.0 \\
22.0\end{array}$ & $\begin{array}{l}8.5 \\
8.5 \\
8.4\end{array}$ & $\begin{array}{l}13.30 \\
14.85 \\
15.26\end{array}$ & $\begin{array}{l}37.42 \\
36.80 \\
35.01\end{array}$ \\
\hline Oct 21 & $\begin{array}{r}0 \\
5 \\
10\end{array}$ & $\begin{array}{r}>18.8 \\
10.1 \\
2.3\end{array}$ & $\begin{array}{l}16.0 \\
17.0 \\
17.0\end{array}$ & $\begin{array}{l}8.2 \\
8.3 \\
8.2\end{array}$ & $\begin{array}{l}16.92 \\
17.34 \\
17.12\end{array}$ & $\begin{array}{l}38.01 \\
38.01 \\
38.01\end{array}$ \\
\hline Nov 22 & $\begin{array}{r}0 \\
5 \\
10\end{array}$ & $\begin{array}{r}>13.7 \\
7.1 \\
2.2\end{array}$ & $\begin{array}{l}12.0 \\
12.0 \\
12.5\end{array}$ & $\begin{array}{l}8.4 \\
8.3 \\
8.4\end{array}$ & $\begin{array}{l}15.56 \\
16.98 \\
16.73\end{array}$ & $\begin{array}{l}39.23 \\
39.23 \\
39.23\end{array}$ \\
\hline Dec 06 & $\begin{array}{r}0 \\
5 \\
10\end{array}$ & $\begin{array}{r}>11.7 \\
0.8 \\
0.2\end{array}$ & $\begin{array}{l}7.5 \\
7.0 \\
7.0\end{array}$ & $\begin{array}{l}8.3 \\
8.3 \\
8.4\end{array}$ & $\begin{array}{l}13.77 \\
14.24 \\
14.42\end{array}$ & $\begin{array}{l}34.00 \\
35.58 \\
36.80\end{array}$ \\
\hline
\end{tabular}


Table 2. Planktonic primary productivity values in the Constantza sector in 1982

\begin{tabular}{|c|c|c|c|c|}
\hline \multirow[t]{2}{*}{ Month } & \multicolumn{3}{|c|}{$\mathrm{mgC} \mathrm{m}^{-3} \mathrm{~h}^{-1}$} & \multirow[t]{2}{*}{$\mathrm{mgC} \mathrm{m}^{-2} \mathrm{~h}^{-1}$} \\
\hline & $0 \mathrm{~m}$ & $5 \mathrm{~m}$ & $10 \mathrm{~m}$ & \\
\hline Jan & 6.0 & 0.2 & 0.2 & 1.7 \\
\hline Feb & 5.1 & 1.4 & 1.4 & 2.3 \\
\hline Mar & 4.8 & 1.9 & 1.5 & 2.5 \\
\hline Apr & 0.6 & 0.5 & 0.3 & 0.5 \\
\hline May & 1.8 & 2.7 & 3.0 & 2.6 \\
\hline Jun & 0.4 & 0.7 & 0.6 & 0.6 \\
\hline Jul & 24.7 & 2.4 & 1.9 & 7.9 \\
\hline Aug & 6.7 & 1.0 & 1.6 & 2.6 \\
\hline Sep & 5.2 & 0.9 & 0.2 & 1.8 \\
\hline Oct & 3.8 & 1.9 & 0.4 & 2.0 \\
\hline Nov & 1.1 & 1.0 & 0.1 & 0.8 \\
\hline Dec & 2.5 & 2.4 & 0.7 & 2.0 \\
\hline $\begin{array}{l}\text { Annual } \\
\text { mean }\end{array}$ & 5.2 & 1.4 & 1.0 & 2.3 \\
\hline
\end{tabular}

$(10 \mathrm{~m})$, were recorded. Maximum productive rates occurred in late spring and summer. These results no longer confirm the usual higher values of primary productivity off the Romanian Black Sea Coast during spring and autumn, as before (e.g. in 1979; Bologa et al., 1981).

The highest $\mathrm{m}^{-2}$ values were $7.9 \mathrm{mg} \mathrm{Ch}^{-1}$ (Jul) and 2.6 (May, Aug). The maximum primary productivity level in Jul is correlated also with the highest chlorophyll a concentrations and with the highest density and biomass values of phytoplankton in 1982.

The lower value of primary productivity in May, compared to previous years (e.g. Bologa et al., 1981), correlated with low chlorophyll a concentrations and with low phytoplankton biomasses, may be explained by the drifting of phytoplankton populations due to upwelling (Table 1). However, also comparatively, it is obvious that not only the lower value in May, but even the maximum value over the whole year, are much lower as compared to the primary productivity level of $1,530 \mathrm{mg} \mathrm{C} \mathrm{m}^{-3} \mathrm{~d}^{-1}$, determined in the Romanian predanubian sector during an extremely intense bloom of Skeletonema costatum also in May 1982 (Bologa et al., 1983).

The vertical distribution of primary productivity showed higher values at $0 \mathrm{~m}$, except in May $(5$ and $10 \mathrm{~m}$ ). The maximum annual mean value occurred also

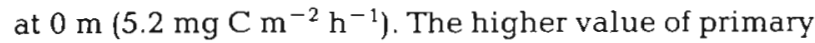
productivity in the surface layers (Fig. 1) agrees with earlier data from the same sector, down to $50 \mathrm{~m}$ depth, in 1980 (Bologa and Frangopol, 1982).

Chlorophyll a concentration values at $0 \mathrm{~m}$ ranged between 0.1 (May) and $3.1 \mathrm{mg} \mathrm{m}^{-3}$ (Jul), at $5 \mathrm{~m}$ between 0.3 (Mar) and 2.3 ( $\mathrm{Jul}$ ) and at $10 \mathrm{~m}$ between 0.1 (Apr) and 1.8 (Jul) in 1982 (Fig. 2). Generally, the

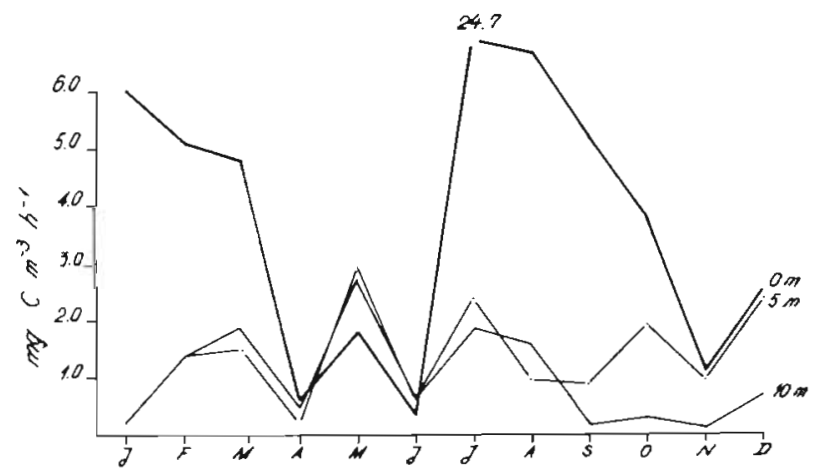

Fig. 1. Annual cycle of planktonic primary productivity at 0,5 and $10 \mathrm{~m}$ in the Constantza nearshore sector

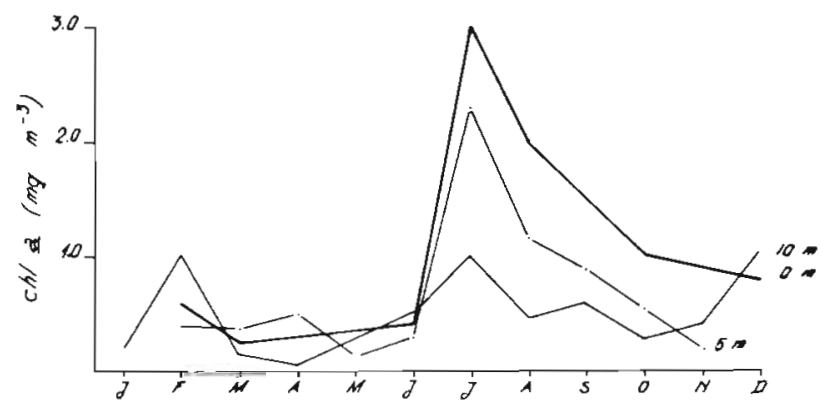

Fig. 2. Annual cycle of chlorophyll a concentrations at 0,5 and $10 \mathrm{~m}$ in the Constantza nearshore sector

values ranged between known limits, e.g. between 0.5 and $1.4 \mathrm{mg} \mathrm{m}^{-3}$ in 1976 (Bologa, 1977) or between 0.3 and 3.6 in 1977 (Bologa, 1978).

The vertical distribution of chlorophyll a shows higher values at $0 \mathrm{~m}$. During intense blooms, a vertical stratification of chlorophyll a concentration, as well as phytoplankton abundance, were observed. The high values of chlorophyll a in Jul and Aug, due to summer blooms, are closely correlated with the high level of primary productivity and with the phytoplankton biomass during this period of the year.

Specific composition and quantitative dynamics of planktonic primary producers were noticed. During this study a total number of 64 species were identified (Table 3).

The annual cycle of phytoplankton density and biomass differs, depending on taxonomic position (Table 4) and water depth (Table 5). The lowest quantities of phytoplankton ( 20 to $25.10^{3}$ cells $l^{-1}$ and 140 to $240 \mathrm{mg} \mathrm{m}^{-3}$ ) were found during Jan, May and Nov which are transitional months. This dominant bloom forming phytoplankton species showed distinct qualitative variations. Thus, in Feb and Mar, the winter species, viz. Thalassiosira subsalina, followed by Skeletonema costatum and Chaetoceros socialis, were dominant. A remarkable dominant population of Gonyaulax polygramma among dinoflagellates was noticed in Apr as had been observed in the previous 
Table 3. Taxonomic composition of planktonic primary producers in the Constantza sector in 1982

\begin{tabular}{|c|c|c|c|c|c|c|c|c|c|c|c|c|c|c|}
\hline \multirow[t]{2}{*}{ No. } & \multirow[t]{2}{*}{ Species } & \multirow[t]{2}{*}{ EG・ } & \multicolumn{12}{|c|}{ Months * } \\
\hline & & & $\mathrm{J}$ & $\mathrm{F}$ & M & A & $M$ & $\mathrm{~J}$ & $\mathrm{~J}$ & A & $\mathrm{s}$ & $\mathrm{O}$ & $\mathrm{N}$ & $\mathrm{D}$ \\
\hline & BACILLARIOPHYTA & & & & & & & & & & & & & \\
\hline 1 & Melosira sulcata (Ehr.) Kütz. & M & & & 0 & & & & & & & & & \\
\hline 2 & Hyalodiscus scoticus (Kütz.) Grun. & M & o & & & & & & & & & & & \\
\hline 3 & Skeletonema costatum (Grev.) Cl. & M & $=$ & $=$ & $\times$ & o & & & & & 0 & $=$ & $\circ$ & $=$ \\
\hline 4 & Thalassiosira excentrica (Ehr.) $\mathrm{Cl}$. & M & o & 0 & & & & & & & & & o & + \\
\hline 5 & $T$. nordenskiöldii $\mathrm{Cl}$ & M & & o & & & & & & & & & & \\
\hline 6 & T. parva Pr.-Lavr. & M & $\mathrm{o}$ & $=$ & 0 & & & & o & & 0 & o & 0 & $=$ \\
\hline 7 & T. subsalina Pr.-Lavr. & M & & $=$ & $=$ & o & & & & & & o & 0 & \\
\hline 8 & Cyclotella caspia Grun. & M & o & & & & & o & & 0 & o & & & \\
\hline 9 & Coscinodiscus concinnus W. Sm. & M & & & & & & 0 & o & 0 & & & & \\
\hline 10 & C. granii Gough. & $\mathbf{M}$ & & o & & & & & & & & & & \\
\hline 11 & Detonula confervacea (Cl.) Gran & M & & & & & & & & & & + & 0 & \\
\hline 12 & Rhizosolenia calcar-avis M. Schultze & M & & & & & & o & & 0 & & o & 0 & \\
\hline 13 & R. fragilissima Bergon & $\mathrm{M}$ & & & & & & o & & & & & 0 & $=$ \\
\hline 14 & Chaetoceros curvisetus Ostf. & $M$ & 0 & & & & & o & & & & o & o & \\
\hline 15 & C. muelleri Lemm. & M & & & & & & & & & & & & + \\
\hline 16 & C. rigidum Ostf. & M & & & & & & & & & & & & $=$ \\
\hline 17 & C. simile $\mathrm{Cl}$. & M & o & o & & & & & & & & & & \\
\hline 18 & C. socialis Laud. & M & & & & & & & & & & $=$ & & + \\
\hline 19 & C. subtile $\mathrm{Cl}$. & M & o & $\times$ & & & & & & & & $=$ & & $=$ \\
\hline 20 & Ditylum brightwelli (West) Grun. & M & o & $\circ$ & 0 & & & o & o & o & & & 0 & $=$ \\
\hline 21 & Cerataulina bergonii Perag. & M & & o & & o & & o & o & + & + & o & 0 & \\
\hline 22 & Thalassionema nitzschioides Grun. & M & & & & & & & & & 0 & $=$ & 0 & o \\
\hline 23 & Diatoma elongatum (Lyngb.) Ag. & $\mathrm{F}$ & 0 & o & 0 & o & o & & & & & & & \\
\hline 24 & Navicula pennata A. S. & M & & o & & 0 & $=$ & & & & & & & \\
\hline 25 & Nitzschia closterium (Ehr.) W. Sm. & M & o & & o & & & o & & $=$ & & o & o & o \\
\hline 26 & N. seriata $\mathrm{Cl}$ & M & & o & 0 & 0 & & o & 0 & 0 & & + & 0 & $=$ \\
\hline & PYRROPHYTA & & & & & & & & & & & & & \\
\hline 27 & Exuviaella cordata Ostf. & M & 0 & $=$ & o & 0 & o & $x$ & $\times$ & $x$ & o & o & $=$ & $=$ \\
\hline 28 & E. compressa Ostf. & M & & o & & o & & & & & & 0 & o & \\
\hline 29 & Prorocentrum micans Ehr. & M & & & & & & 0 & & o & & 0 & 0 & $\circ$ \\
\hline 30 & $P$ scutellum Schröder & M & & & & & & 0 & & & & & & o \\
\hline 31 & Phalacroma rotundatum Kof. et Mich. & M & & & & & & & & & & & o & \\
\hline 32 & Dinophysis fortii Pav. & M & & & & & & & & & & & & o \\
\hline 33 & D. sacculus & M & & & & o & & & & & & & & \\
\hline 34 & Gymnodinium rhomboides Scütt. & $M$ & & o & o & & & & & & & $=$ & o & o \\
\hline 35 & G. splendens Lebour & M & & & & 0 & & & & & & & & \\
\hline 36 & Gyrodinium fusiforme Kof. et Sw. & M & & & & & o & $=$ & o & & & 0 & o & o \\
\hline 37 & G. lachryma Kof. et Sw. & M & & o & & 0 & 0 & 0 & & & & & & \\
\hline 38 & Glenodinium apiculatum Zach. & M & & o & & & & & 0 & o & & & & \\
\hline 39 & G. lenticula Bergh & $\mathbf{M}$ & & & & & & & & 0 & o & & 0 & \\
\hline 40 & Peridinium brevipes Paulsen & M & & o & o & 0 & o & & & & & o & $o$ & o \\
\hline 41 & P. crassipes Kof. & M & & & & o & & o & & & & & & \\
\hline 42 & P. depressum Bailey & M & & & & & & & 0 & & & & & \\
\hline 43 & P. minusculum Pav. & M & & & & & & & & & & & o & \\
\hline 44 & P. pentagonum Gran & M & & 0 & & & & & & & & & & \\
\hline 45 & P. steinil Jörg & M & o & 0 & & & & & $=$ & & & & & o \\
\hline 46 & Gonyaulax polygramma Stein & M & o & 0 & o & $=$ & $\circ$ & o & & & & & & $=$ \\
\hline 47 & Ceratium furca Ehr. & M & & & & & & & & o & & o & o & $=$ \\
\hline 48 & C. fusus (Ehr.) Duj. & & & & & & & & 0 & 0 & & & & o \\
\hline 49 & C. tripos (O. F. Müller) Nitzsch & M & & & & & & & 0 & o & & & o & o \\
\hline 50 & Protoceratium reticulatum Bütschli & M & & & & & & & & & & & 0 & o \\
\hline 51 & Hypnodinium sphaericum Klebs & $M$ & & & & o & & $=$ & o & & & & & \\
\hline & Pyrrophyta kysts? & M & o & & & & & & $=$ & & & o & & \\
\hline & CHLOROPHYTA & & & & & & & & & & & & & \\
\hline 52 & Ankistrodesmus falcatus (Corda) Ralfs & $F$ & & & & & & & & & & 0 & 0 & o \\
\hline 53 & Crucigenia tetrapedia West et G. S. West & $\mathrm{F}$ & & & & & & & & & & & & o \\
\hline 54 & Lagerheimia sp. & $\mathrm{F}$ & & o & & & & & & & & & & \\
\hline 55 & Pterospentna cristatum Schiller & M & & o & & & & o & & & & o & 0 & \\
\hline
\end{tabular}


Table 3. Continued

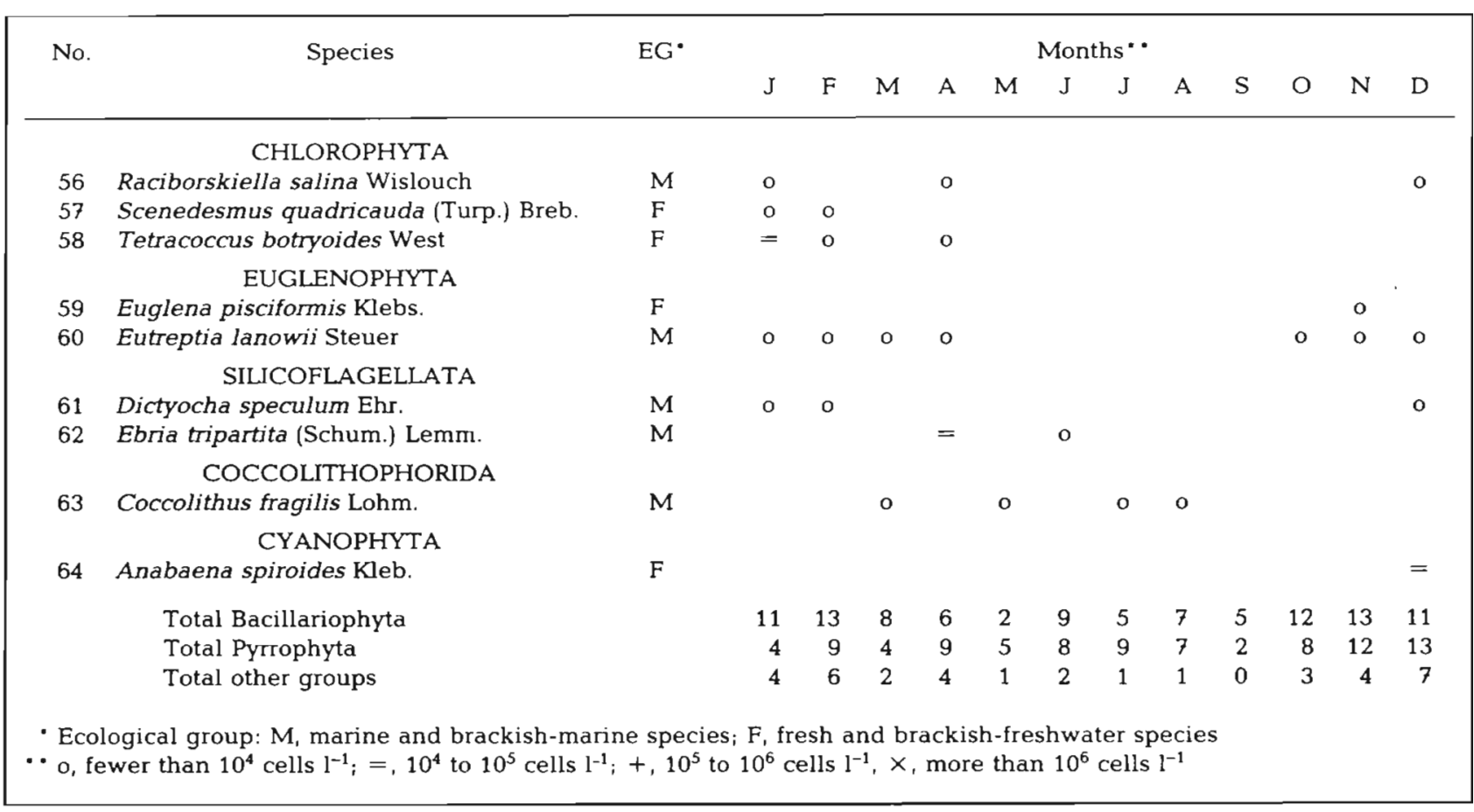

Table 4. Density and biomass dynamics of planktonic primary producers as a function of taxanomic position in the Constantza sector in 1982

\begin{tabular}{|c|c|c|c|c|}
\hline Month & Bacillariophyta & Pyrrophyta & Other groups & Total \\
\hline \multicolumn{5}{|c|}{ Density (cells $\mathrm{l}^{-1}$ ) } \\
\hline Jan & 11,725 & 5,500 & 7,875 & 25,100 \\
\hline Feb & 177,250 & 11,500 & 7,000 & 195,750 \\
\hline Mar & 327,125 & 3,375 & 375 & 330,875 \\
\hline Apr & 13,125 & 74,000 & 42,250 & 129,375 \\
\hline May & 11,625 & 9,125 & 125 & 20,875 \\
\hline Jun & 12,375 & $7,038,875$ & 375 & $7,051,625$ \\
\hline Jul & 3,000 & $35,752,500$ & 125 & $35,755,625$ \\
\hline Aug & 68,625 & $1,871,250$ & 625 & $1,940,500$ \\
\hline Sep & 188,625 & 1,875 & 0 & 190,500 \\
\hline Oct & 272,250 & 18,875 & 3,500 & 294,625 \\
\hline Nov & 9,750 & 12,625 & 875 & 23,250 \\
\hline Dec & 483,125 & 72,375 & 16,375 & 571,875 \\
\hline Annual mean & 131,550 & $3,739,323$ & 6,625 & $3,877,498$ \\
\hline \multicolumn{5}{|c|}{ Biomass (mg m ${ }^{-3}$ ) } \\
\hline Jan & 79.96 & 54.57 & 4.75 & 139.29 \\
\hline Feb & $2,566.54$ & 108.76 & 20.45 & $2,695.77$ \\
\hline Mar & $1,698.33$ & 70.48 & 1.94 & $1,770.75$ \\
\hline Apr & 329.84 & 820.79 & 95.34 & $1,245.97$ \\
\hline May & 22.50 & 129.01 & 1.76 & 153.28 \\
\hline Jun & 582.28 & $7,672.50$ & 0.49 & $8,255.49$ \\
\hline Jul & 117.05 & $28,444.57$ & 0.87 & $28,562.50$ \\
\hline Aug & 871.74 & $1,571.30$ & 4.37 & $2,447.42$ \\
\hline Sep & 4.113 .20 & 8.77 & 0 & $4,121.97$ \\
\hline Oct & 371.08 & 289.73 & 3.07 & 663.89 \\
\hline Nov & 96.83 & 141.11 & 0.94 & 238.88 \\
\hline Dec & $1,129.49$ & 984.94 & 12.00 & $2,126.43$ \\
\hline Annual mean & 998.24 & $3,358.03$ & 12.16 & $4,368.47$ \\
\hline
\end{tabular}


Table 5. Density and biomass dynamics of planktonic primary producers depending on the depth in the Constantza sector in 1982

\begin{tabular}{|c|c|c|c|c|}
\hline Month & $0 \mathrm{~m}$ & $5 \mathrm{~m}$ & $10 \mathrm{~m}$ & Mean \\
\hline \multicolumn{5}{|c|}{ Density (cells l $^{-1}$ ) } \\
\hline Jan & 44,500 & 9,200 & 37,500 & 25,100 \\
\hline Feb & 65,000 & 298,500 & 121,000 & 195,750 \\
\hline Mar & $1,222,500$ & 40,500 & 20,000 & 330,875 \\
\hline Apr & 99,500 & 177,500 & 63,000 & 129,375 \\
\hline May & 19,500 & 28,000 & 8,000 & 20,875 \\
\hline Jun & $26,420,500$ & 482,000 & 822,000 & $7,051,625$ \\
\hline Jul & $54,722,000$ & $31,287,000$ & $25,726,500$ & $35,755,625$ \\
\hline Aug & $2,034,000$ & $1,787,000$ & $2,154,000$ & $1,940,500$ \\
\hline Sep & 361,500 & 195,000 & 10,500 & 190,500 \\
\hline Oct & 556,000 & 219,500 & 183,500 & 294,625 \\
\hline Nov & 23,500 & 8,500 & 52,500 & 23,250 \\
\hline Dec & 484,500 & 568,000 & 667,000 & 571,875 \\
\hline Annual mean & $7,171.083$ & $2,925,058$ & $2,488,792$ & $3,877,498$ \\
\hline \multicolumn{5}{|c|}{ Biomass ( $\mathrm{mg} \mathrm{m}^{-3}$ ) } \\
\hline Jan & 194.90 & 87.58 & 187.09 & 139.29 \\
\hline Feb & 594.37 & $3,229.22$ & $3,491.35$ & $2,586.16$ \\
\hline Mar & $2,378.82$ & $1,959.52$ & 785.14 & $1,770,75$ \\
\hline Apr & 749.94 & $1,519.75$ & $1,194.45$ & $1,245.97$ \\
\hline May & 264.62 & 151.56 & 45.38 & 153.28 \\
\hline Jun & $21,677.96$ & $3,444.85$ & $4,454.32$ & $8,255.49$ \\
\hline Jul & $42,764.60$ & $24,895.40$ & $21,694.60$ & $28,562.50$ \\
\hline Aug & $2,441.97$ & $1,779.90$ & 3.817 .90 & $2,447.42$ \\
\hline Sep & $7,888.78$ & $4,189.36$ & 220.39 & $4,121.97$ \\
\hline Oct & 898.28 & 600.20 & 556.88 & 663.89 \\
\hline Nov & 391.77 & 75.70 & 412.38 & 238.88 \\
\hline Dec & $1,447.90$ & $2,020.42$ & $3,016.98$ & $2,126.43$ \\
\hline Annual mean & $6,805.32$ & 3.672 .56 & $3,323.07$ & $4,368.47$ \\
\hline
\end{tabular}

years. The weight of the diatoms also decreased during this period.

In May the quantities of these species decreased considerably. A bloom of Exuviaella cordata commenced in Jun, and continued until it decreased in Aug. During Aug a rich population of Cerataulina bergonii started; it attained a maximum concentration in Sep.

A small number of species (fewer than 20) was recorded round the year except in Feb (28 species); their number had particularly declined in May ( 8 species) when the phytoplankton was poor and in Sep (7 species) when Cerataulina bergonii probably inhibited the development of other species, as had been observed for other diatom species (Aubert et al., 1981).

Since Oct the phytoplankton diversity increased continuously, owing to the appearance of autumn and winter species, besides the summer species.

Towards end of Oct Detonula confervacea, Thalassionema nitzschioides, Nitzschia seriata and Skeletonema costatum appeared in the plankton in high quantities. However, the abundance of all the above-named species was less in Nov. In Dec, S. costatum, Thalassiosira excentrica, Chaetoceros socialis and $C$. muelleri became dominant among the diatoms, and Exuviaella cordata and Gonyaulax polygramma among the dinoflagellates.

In our samples, species belonging to 7 phyla were found, among which diatoms $(41.0 \%)$ and dinoflagellates $(39.0 \%)$ were dominant; the other 5 phyla represented only $20 \%$ of the total number of species (Table 6).

Primary producers were analysed also from the ecological point of view. Because of the large variation in salinity conditions in the Constantza sector, the brackish-freshwater species represented $12.5 \%$, and the brackish-marine species $87.5 \%$ (Table 7). These values are similar to those reported earlier, viz. 15.5 and $84.5 \%$, respectively for 1979 (Bologa et al., 1981).

The values of primary productivity reported here are lower than those reported for 55 samples from $0 \mathrm{~m}$ in 1979 (Bologa et al., 1981) and for 130 samples from 0 , 10, 25 and $50 \mathrm{~m}$ in 1980 (Bologa and Frangopol, 1982). The lower values could be due - in spite of the high nutrient concentrations $\left(\mathrm{P}-\mathrm{PO}_{4}\right)$ which still occur - to the decreasing tendency of eutrophication beginning in 1975 and continuing until 1982: $10.2 \mathrm{mg} \mathrm{m}^{-3}$ in 1959 to $1970,302.6$ in $1975,173.9$ in 1971 to 1982 , and 158.4 
Table 6. Number and percentage of phytoplankton species belonging to different taxonomic groups

\begin{tabular}{|lrr|}
\hline Taxonomic group & \multicolumn{2}{c|}{ Species } \\
& number & $\%$ \\
\hline Bacillariophyta & 26 & 41.00 \\
Pyrrophyta & 25 & 39.00 \\
Chlorophyta & 7 & 10.80 \\
Euglenophyta & 2 & 3.12 \\
Silicoflagellata & 2 & 3.12 \\
Coccolithophorida & 1 & 1.56 \\
Cyanophyta & 1 & 1.56 \\
Total & 64 & 100.00 \\
\hline
\end{tabular}

Table 7. Distribution of ecological groups of the planktonic primary producers in the Constantza sector in 1982

\begin{tabular}{|lrr|}
\hline \multirow{2}{*}{ Ecological group } & \multicolumn{3}{c|}{ Species } \\
& number & $\%$ \\
\hline Marine and brackish-marine species & 56 & 87.5 \\
Fresh and brackish-freshwater species & 8 & 12.5 \\
Total & 64 & 100.0 \\
\hline
\end{tabular}

in 1982 (Cociaşu and Popa, 1980; Voinescu et al. 1981; Cociașu et al., pers. comm.). Nevertheless, the same sequence of microalgal populations which have dominated the phytoplankton of Romanian coastal waters since 1974 has been observed. Two maxima of phytoplankton development could be delimited quite distinctly until then in these waters: a stronger one in spring and a weaker one in autumn. These maxima were strongly linked to the 2 high floods of the Danube (Skolka and Bodeanu, 1978). Beginning with the eutrophication of the sea, the spring bloom caused by the diatom complex Skeletonema-Thalassiosira was replaced by the dinoflagellate Gonyaulax polygramma; this, in turn, was gradually replaced by the very intense Exuviaella cordata bloom, which lasted until Aug. Under such circumstances the summer minimum can either be blurred or even replaced by the annual maximum of phytoplankton development (Bodeanu and Roban, 1975; Bodeanu and Uşurelu, 1979). Hence, there is only one winter phytoplankton minimum during one annual cycle, due to diminution of light energy. However, this winter minimum can also become shorter, or may even occur at the outset of a winter-spring bloom (during a cloudless sky and high temperatures) as was the case in Dec 1982.

\section{CONCLUSIONS}

(1) Planktonic primary productivity in the Constantza sector, nearshore, amounts to $5.2,1.4$ and $1.0 \mathrm{mg} \mathrm{C} \mathrm{m} \mathrm{C} \mathrm{h}^{-1}$ at 0,5 and $10 \mathrm{~m}$, respectively; the water-column value was $2.3 \mathrm{mg} \mathrm{C} \mathrm{m}^{-2} \mathrm{~h}^{-1}$ in 1982 .

(2) Quantitatively, primary productivity was correlated with chlorophyll a concentrations and phytoplankton biomass, especially in terms of increased production levels.

(3) The maximum primary productivity value in Jul 1982 was due to the intense bloom of the dinoflagellate Exuviaella cordata.

(4) Exuviaella cordata has produced blooms of different intensities every year since 1974. Accordingly, the original seasonal occurrence of phytoplankton at the Romanian Black Sea Coast, with spring and autumn maxima and with winter and summer minima, became blurred or even disappeared completely.

(5) Maximum primary productivity values occurred, with few exceptions, at $0 \mathrm{~m}$, not at 5 or $10 \mathrm{~m}$.

Acknowledgements. We sincerely thank Mr. N. Mustafa for technical assistance during sampling and exposure of samples under in situ conditions.

\section{LITERATURE CITED}

Aubert, M., Gauthier, M., Aubert, J., Bernard, P. (1981). Les systems d'information des micro-organismes marins. Leur rôle dans l'équilibre biologique océanique. Ed. Rev. Int. Océanogr. Méd.: 5-231

Bodeanu, N., Roban, A. (1975). Données concernant la floraison des eaux du littoral roumain de la mer Noire avec le péridinien Exuviaella cordata. Cercet. mar.-Rech. mar 8: 43-62

Bodeanu, N., Uşurelu, M. (1979). Dinoflagellate blooms in Romanian Black Sea coastal waters. In: Taylor, D. L. Selinger, H. H. (ed.) Toxic dinoflagellate blooms, Proc. 2nd Intl. Conf. Toxic Dinoflagellate Blooms, Developments Marine Biology. Vol. I. Elsevier North Holland Inc., N. Y., Ansterdam, Oxford, p. 151-154

Bologa, A. S. (1977). The phytoplanktonic assimilatory pigments along the Romanian coast of the Black Sea during 1976. Cercet. mar.-Rech. mar. 10: 95-107

Bologa, A. S. (1978). The monthly dynamics of phytoplanktonic assimilatory pigments from the sector ConstantzaAgigea of Romanian Black Sea coast during 1977. Cercet. mar.-Rech. mar. 11: 77-83

Bologa, A. S., Frangopol, P. T., Frangopol, M., Stanef, I. (1980). Marine phytoplankton photosynthesis in the offshore zone of Constantza (Black Sea) during JuneDecember 1978. Rev. Roum. Biol.-Biol. Végét. 25: 129-133

Bologa, A. S., Uşurelu, M., Frangopol, P. T. (1981). Planktonic primary productivity of the Romanian surface coastal waters (Black Sea) in 1979. Oceanologica Acta 4: 343-349

Bologa, A. S., Frangopol, P. T. (1982). Data on the vertical distribution of planktonic primary productivity in the offshore zone of Constantza (Black Sea). Rev. Roum. Biol.Biol. Végét. 28: 141-146 
Bologa, A. S., Burlakova, Z. P., Tchmyr, V. D., Kholodov, V. I. (1983). Données sur la distribution de la chlorophylle a et de la production primaire dans la partie ouest de la mer Noire. Rapp. P.-v. Réun. Commn int. Explor. scient. Mer Méditerr. 28: 79-81

Cociaşu, A., Popa, L. (1980). Observations sur l'évolution des principaux paramètres physico-chimiques de l'eau marine de la zone Constanța. Cercet. mar.-Rech. mar. 13: 51-61

Gaastra, P. (1959). Photosynthesis of crop plants as influenced by light, carbon dioxide, temperature, and stomatal diffusion resistence. Meded. Landbouwhogesch. (Wageningen) 59: 1-68

Kubin, S. (1971). Measurement of radiant energy. In: Sesták, Z., Catský, J., Jarvis, P. G. (ed.) Plant photosynthetic production. Manual of methods. Dr. W. Junk N. V., Publ., The Hague, p. 702-765

Morozova-Vodyanitskaya, N. V. (1948). Fitoplankton Tchernogo moria, 1. Trudy sevastopol', biol. Sta. 6: 39-172

Morozova-Vodyanitskaya, N. V. (1954). Fitoplankton Tchernogo moria, 2. Trudy sevastopol' . biol. Sta. 8: 11-99

Protecţia calității apelor (Water Quality Control) (1967). Biblioteca Standardelor, Ser. Tehn. A 62: 137-138

Richards, F. A., Thompson, T. G. (1952). The estimation and characterization of plankton populations by pigment analysis. II. A spectrophotometric method for estimation of plankton pigments. J. mar. Res. 11: 156-172

Skolka, H. V., Bodeanu, N. (1978). Fitoplanctonul de la litoralul românesc şi eutrofizarea mării. In: Ionescu, A., Sion, I., Stanciu, M. (ed.) Protecţia ecosistemelor. Constanța: 162-166

Sournia, A. (1973). La production primaire planctonique en Méditerranée. Essai de mise à jour. Bull. Etud. Comm. Méditer. Num. spéc. 5: 1-128

Steemann Nielsen, E. (1952). The use of radiocarbon $\left(C^{14}\right)$ for measuring organic production in the sea. J. Cons. perm. int. Explor. Mer 18: 117-140

Strickland, J. D. H., Parsons, T. R. (1968). Particulate organic matter. Determination of photosynthetic pigments. Fish. Res. Bd Can. 125: 107-112

Unesco (1966). Determination of photosynthetic pigments. In: Determination of photosynthetic pigments in sea-water. Unesco, Paris, p. 9-18 (Monographs on oceanographic methodologyj

Vinberg, G. G., Kabanova, J. G., Kaler, V. L., KoblentzMishke, O. I., Khmeleva, N. N. (1960). Metoditcheskoje posobia po opredeleniju pervitchnoy produktsii organitcheskogo vestchestva $v$ vodojemakh radiouglerodnym metodom. Izd. AN SSSR, Minsk, p. 1-26

Voinescu, I., Cociaşu, A., Dorogan, L. (1981). Considération sur le rapport N/P dans les eaux marines du littoral roumain de la mer Noire. Cercet. mar.-Rech. mar. 14: 77-89

Zaitsev, I. P. (1979). Problèmes biologiques de la partie nord. ouest de la mer Noire. Cercet. mar.-Rech. mar. 12: 7-32

This paper was submitted to the editor; it was accepted for printing on April 30, 1984 